\title{
The impact of standard and low-pressure pneumoperitoneum on hydration in obese females undergoing laparoscopic cholecystectomy
}

\author{
Wpływ standardowo- i niskociśnieniowej odmy otrzewnowej na stan nawodnienia \\ otyłych kobiet poddanych laparoskopowej cholecystektomii
}

\author{
Łukasz Pietrzyk ${ }^{1,2}$, Marta Denisow-Pietrzyk ${ }^{1}$, Anna Torres ${ }^{3}$, Kamil Torres ${ }^{1}$ \\ 1Department of Didactics and Medical Simulation, Chair of Human Anatomy, Medical University of Lublin, Poland \\ Head of the Department: Assoc. Prof. Kamil Torres, MD, PhD \\ 2Department of General, Oncological, and Minimally Invasive Surgery, $1^{\text {st }}$ Clinical Military Hospital with the Outpatient Clinic, Lublin, Poland \\ Head of the Department: Dr. Zbigniew Plewa, MD, PhD \\ ${ }^{3}$ Laboratory of Biostructure, Chair and Department of Human Anatomy, Medical University of Lublin, Poland \\ Head of the Chair and Department: Prof. Ryszard Maciejewski, MD, PhD
}

Key words: obesity, pneumoperitoneum, hydration status, cholecystectomy, bioimpedance.

Słowa kluczowe: otyłość, odma otrzewnowa, stan nawodnienia, cholecystektomia, bioimepdancja.

\begin{abstract}
Introduction: Disturbances in hydration status can increase the frequency of post-operative pain, nausea and vomiting (PONV), complicate the wound healing process and thus, increase the period of hospitalization, especially in overweight and obese patients. Aim of the research: To assess the impact of the standard and low-pressure pneumoperitoneum on hydration status of obese female patients undergoing laparoscopic cholecystectomy in the early post-operative period.

Material and methods: The study included 52 female individuals with asymptomatic cholelithiasis who underwent laparoscopic cholecystectomy. Patients were assigned to three groups according to the body mass index and value of intraabdominal pressure. Evaluation of the hydration status was performed at three time points: point 0 - before the operation, point $24-24$ hour after the surgery, and point $48-48$ hours after the surgery.

Results: A higher total body water (TBW) and dehydration was observed in obese compared to normal weight patients in the time point 24 and 48. Extracellular water (ECW) was significantly higher in obese compared to normal weight patients in the time studied time point. Intracellular water (ICW) and ECW/ICW did not differ significantly between the studied groups in the studied time. Conclusions: Obesity alters the hydration status. Values of carbon-dioxide pneumoperitoneum pressure used during short duration laparoscopic surgery did not have an influence on the hydration status of the obese female patients.
\end{abstract}

\section{Streszczenie}

Wprowadzenie: Zaburzenia stanu nawodnienia mogą zwiększyć częstość nudności i wymiotów pooperacyjnych, zaburzyć proces gojenia ran, a przez to wydłużyć okres hospitalizacji, szczególnie w grupie pacjentów z nadwagą i otyłych.

Cel pracy: Ocena wpływu standardowo- i niskociśnieniowej odmy otrzewnowej na stan nawodnienia we wczesnym okresie pooperacyjnym w grupie otyłych kobiet poddanych laparoskopowej cholecystektomii.

Materiał i metody: Badanie przeprowadzono w grupie 52 kobiet z bezobjawową kamicą pęcherzyka żółciowego poddanych laparoskopowej cholecystektomii. Pacjentki zostały podzielone na trzy grupy w zależności od wskaźnika masy ciała i wartości ciśnienia odmy otrzewnowej. Ocena stanu nawodnienia została przeprowadzona w trzech punktach czasowych: punkt 0 - przed zabiegiem chirurgicznym, punkt 24 . - w 24. godzinie pooperacyjnej, i punkt 48. - w 48. godzinie pooperacyjnej. Wyniki: Wyższą wielkość całkowitej wody ustroju i niższą wartość stanu nawodnienia zaobserwowano w grupie pacjentek otyłych w porównaniu z grupą pacjentek z normalną masą ciała w punkcie 24 . i 48 . Wielkość przestrzeni wodnej zewnątrzkomórkowej (extracellular water - ECW) była istotnie statystycznie większa w grupie pacjentek otyłych w porównaniu z grupa pacjentek z normalną masa ciała w trzech badanych punktach. Wielkość przestrzeni wodnej wewnatrzkomórkowej (intracellular water - ICW) i stosunek ECW/ICW nie różniły się istotnie statystycznie pomiędzy badanymi grupami pacjentek w badanych punktach czasowych.

Wnioski: Otyłość wpływa na stan nawodnienia. Wartość ciśnienia odmy otrzewnowej podczas krótkiego zabiegu laparoskopowego nie wpływa na stan nawodnienia otyłych pacjentek. 


\section{Introduction}

Obesity, according to the World Health Organization, has become one of the leading epidemic diseases in the world $[1,2]$. Obesity influences the course of the post-operative period, which was reported to be more complicated and more commonly included occurrences of respiratory complications, wound infection with dehiscence, venous thrombus, and pulmonary embolism [3, 4].

Laparoscopic cholecystectomy is one of the most commonly used surgical procedures performed in Surgical Departments worldwide [5]. The pneumoperitoneum may cause deterioration of cardiovascular and respiratory systems and perfusion decrease of abdominal viscera, and is considered as a fundamental risk factor for post-operative nausea and vomiting, which occurs in approximately $25-30 \%$ of patients, especially in obese females undergoing laparoscopic procedures [6-9].

Hydration status is one of the most important factors that influence the course of the early post-operative period. Disturbances of the hydration status can increase the frequency of postoperative pain, nausea and vomiting (PONV), complicate the wound healing process in the mechanism of decreased cardiac output, tissue perfusion and thus, increase the period of hospitalization $[10,11]$. These complications may be present especially in overweight and obese patients, in whom an excessive amount of adipose tissue results in changes in the fat-free mass, and the total and extracellular amount of body water $[12,13]$.

\section{Aim of the research}

The aim of the study was to assess the impact of obesity, the standard and low-pressure carbon dioxide pneumoperitoneum on hydration status of obese female patients undergoing laparoscopic cholecystectomy in the early postoperative period.

\section{Material and methods}

The study included 52 female individuals with asymptomatic cholelithiasis, confirmed by an ultrasound examination, treated in the Department of General, Oncological and Minimally Invasive Surgery of the $1^{\text {st }}$ Military Clinical Hospital with the Outpatient Clinic in Lublin, Poland. All patients were informed about the aims of the study and written consent was obtained from each patient. The study was approved by the Ethical Committee at the Medical University of Lublin (decision No: KE-0254/247/2012).

Patients with acute inflammation of the gallbladder, diabetes, thyroid and autoimmune disease, allergies, past surgical procedures in the abdominopelvic cavity, and with cases of ectopic pregnancies were excluded from the study.
All patients underwent laparoscopic cholecystectomy using a standard four-trocar technique. Carbon dioxide pneumoperitoneum was obtained with a veress needle. In the standard pressure group, intra-abdominal pressure of 12-14 mmHg was maintained throughout the procedure, whereas in patients from the second group pressure of 6-8 $\mathrm{mmHg}$ was applied to perform surgery. The general anesthesia method was the same for both groups. Anatomic recognition of Calot's triangle was performed in each case. The cystic duct and cystic artery were clipped and cut. The gallbladder was removed in a medical protector through an incision below the umbilicus. A histopathological examination of collected tissues did not reveal any malignancies.

Patients were assigned to three groups according to the body mass index (BMI) and value of intra-abdominal pressure. Patients undergoing laparoscopic surgery using the standard value of intra-abdominal pressure (12-14 mmHg) with BMI $<25 \mathrm{~kg} / \mathrm{m}^{2}$ were enrolled in group $\mathrm{N}$, while patients with $\mathrm{BMI} \geq 30 \mathrm{~kg} / \mathrm{m}^{2}$ were classified to group OS. Patients with BMI $\geq 30 \mathrm{~kg} / \mathrm{m}^{2}$ and undergoing laparoscopic surgery, with low-pressure $(6-8 \mathrm{mmHg})$ pneumoperitoneum were enrolled to group OL.

Evaluation of the hydration status was performed at three time points: point 0 - before the surgical procedure, point $24-24$ hours after the beginning of the procedure, and point $48-48$ hours after the beginning of the procedure. The following parameters indicating the state of hydration of patients were determined in each case: total body water (TBW), extracellular water (ECW), intracellular water (ICW), ECW/ ICW ratio, and state of overhydration $(\mathrm{OH})$.

Evaluation of the hydration status was performed at three time points: time point 0 - before the surgical procedure, time point $24-24$ hours after the beginning of the surgery, and time point $48-48$ hours after the beginning of the surgery. Changes of measured parameters were evaluated in three time periods. Period 0-24: value at 24 hours after the beginning of the surgery to the value before the surgery, period 24-48: value at 48 hours after the beginning of the surgery to the value at 24 hours after the beginning of the surgery, and period 0-48: value at 48 hours after the beginning of the surgery to the value before the surgery. TBW, ECW, ICW, and fluid volume excess were measured by whole-body BIA using a body composition monitor (BCM, Fresenius Medical Care, Bad Homburg, Germany). Prior to examinations, patients' blood pressure and heart rate were measured. Electrode pairs were placed on the wrist, proximally to the metacarpophalangeal joints, and on the ankle, proximally to the transverse metatarsal arch on the dorsal side of the foot, for current injection and voltage measurement. Bioimpedance was measured at 50 frequencies, ranging from $5 \mathrm{kHz}$ to $1 \mathrm{MHz}$ in supine body position. The data was achieved after approximately 1 minute and then subjected to statistical analysis. 
The Kolmogorov-Smirnov test was performed to check the normal distribution of data. Normally distributed parametric data were presented as means and standard deviations (SD), while non-parametric data were presented as median and min-max values. Differences between groups were analyzed using student's unpaired $t$-test for variables with normal distribution and Mann-Whitney $U$ test for non-parametric variables. Differences from baseline within each group were evaluated with the Wilcoxon match-pairs signed ranks test. Correlation between data was performed using the Spearman's rank correlation tests. Differences of $p<0.05$ were considered to be significant. Statistical analysis was performed using 16.0 SPSS software.

\section{Results}

\section{Patients' characteristics}

Patients' characteristics are presented in Table 1.

Significantly higher BMI and abdominal circumferences at the level of umbilicus and ASIS were observed in group OS in comparison to group N. There were no differences between groups OL and OS with respect to BMI.

Before the surgery, each patient was assessed according to the ASA scale with no significant differences between groups. Additionally, there were no differences in hematological (hemoglobin, HCT, PLT) and biochemical parameters (AST, ALT, bilirubin, creatinine) examined before and after the surgery. The median body temperature and white blood count (WBC) was similar (normal ranges) in both groups during the postoperative time.
There was no significant difference in duration of surgery when the three groups were compared. The median duration of surgery was 47.50 minutes in group $\mathrm{N}$, and 50 minutes in group OS and OL.

\section{Total body water}

TBW was significantly higher in group OS in comparison to group $\mathrm{N}$ before and 24 hours after the operation ( $p=0.002$ and $p=0.007$, respectively). There were no significant differences in TBW amount between groups OL and OS in the studied time points. This is presented in Table 2.

TBW decreased significantly $(p<0.05)$ in the $24^{\text {th }}$ postoperative hour compared to the TBW in the $48^{\text {th }}$ hour after surgery (period 24-48) in group OL. In the group $\mathrm{N}$ and OS, there was no significant change in the TBW in the studied time periods.

TBW elevated in the studied time points was correlated in each group with the patients' age and BMI values. Significant negative $(r=-0.713 ; p=0.009)$ correlation between the TBW in the $24^{\text {th }}$ post-operative hour and the age of patients was observed. A significant positive correlation between TBW and BMI values was observed in group OS in the $24^{\text {th }}$ hour after surgery and in group OL in the $48^{\text {th }}$ hour after surgery (for group OS: $r=0.535, p=0.018$; for group OL: $r=0.477$, $p=0.033)$.

\section{Extracellular water}

ECW was significantly higher in group OS in comparison to group $\mathrm{N}$ in the studied time points $(p<0.001$ - time point $0 ; p=0.001$ - time point 24 ;

Table 1. Patients' characteristics

\begin{tabular}{|c|c|c|c|c|}
\hline Factor & Group & $n$ & Median & Min-Max \\
\hline \multirow[t]{3}{*}{ Age (years) } & $\mathrm{N}$ & 12 & 45.00 & $18.00-60.00$ \\
\hline & OS & 20 & 54.00 & $27.00-65.00$ \\
\hline & $\mathrm{OL}$ & 20 & 55.00 & $25.00-65.00$ \\
\hline \multirow[t]{3}{*}{ BMI $\left(\mathrm{kg} / \mathrm{m}^{2}\right)^{*}$} & $\mathrm{~N}$ & 12 & 22.55 & $19.33-24.09$ \\
\hline & OS & 20 & 33.36 & $30.01-39.33$ \\
\hline & $\mathrm{OL}$ & 20 & 32.21 & $30.15-34.71$ \\
\hline \multirow{3}{*}{$\begin{array}{l}\text { Waist circumference at the level } \\
\text { of the umbilicus }(\mathrm{cm})^{*}\end{array}$} & $\mathrm{~N}$ & 12 & 79.00 & 46.00-93.00 \\
\hline & OS & 20 & 105.50 & $80.00-120.00$ \\
\hline & $\mathrm{OL}$ & 20 & 93.50 & $85.00-106.00$ \\
\hline \multirow{3}{*}{$\begin{array}{l}\text { Waist circumference at the level } \\
\text { of the ASIS }(\mathrm{cm})^{\star}\end{array}$} & $\mathrm{N}$ & 12 & 96.50 & $50.00-103.00$ \\
\hline & OS & 20 & 111.00 & $99.00-128.00$ \\
\hline & $\mathrm{OL}$ & 20 & 110.50 & 92.00-118.00 \\
\hline
\end{tabular}

$n$ - number of patients, ASIS - anterior superior iliac spine

* - statistically significant difference in Mann Whitney U-test group N vs. OS 
Table 2. Median of patients' total body water (TBW) in groups N, OS, and OL before surgery, 24, and 48 hours after the surgery

\begin{tabular}{|lccc|}
\hline Factor & Group N & Group OS & Group OL \\
\cline { 2 - 4 } & Median & Median & Median \\
& Min-max & Min-max & Min-max \\
& $(\mathrm{l})$ & $(\mathrm{l})$ & 30.70 \\
TBW & 28.25 & 33.90 & $28.10-40.90$ \\
Time point 0* & $25.00-33.70$ & $28.50-50.20$ & 31.80 \\
TBW & 28.70 & 33.00 & $26.20-38.00$ \\
Time point 24* & $25.40-33.70$ & $28.00-42.20$ & 30.90 \\
TBW & 28.75 & 31.60 & $27.50-36.40$ \\
Time point 48 & $24.50-35.70$ & $28.00-43.50$ & \\
\hline
\end{tabular}

Min-max - range of values

* - statistically significant difference in Mann-Whitney U test group N vs. OS

Table 3. Median of patients' extracellular water (ECW) in groups N, OS, and OL before surgery, 24 , and 48 hours after the surgery

\begin{tabular}{|lccc|}
\hline Factor & Group N & Group OS & Group OL \\
\cline { 2 - 4 } & $\begin{array}{c}\text { Median } \\
\text { Min-max } \\
(\mathbf{l})\end{array}$ & $\begin{array}{c}\text { Median } \\
\text { Min-max } \\
(\mathrm{I})\end{array}$ & $\begin{array}{c}\text { Median } \\
\text { Min-max } \\
(\mathrm{I})\end{array}$ \\
ECW & 12.40 & 14.95 & 15.30 \\
Time point 0* & $10.90-15.50$ & $12.80-19.40$ & $12.80-17.70$ \\
ECW & 13.15 & 14.80 & 15.80 \\
Time point 24* & $11.50-15.00$ & $13.40-19.70$ & $13.90-18.40$ \\
ECW & 12.80 & 14.50 & 15.50 \\
Time point 48* & $11.00-15.40$ & $13.00-19.00$ & $13.70-18.60$ \\
\hline
\end{tabular}

Min-max - range of values

* - statistically significant difference in Mann Whitney U-test group N vs. OS

$p=0.002$ - time point 48). No significant differences in the amount of ECW were observed between groups OS and OL. Results are presented in Table 3.

ECW increased significantly $(p<0.05)$ in the $24^{\text {th }}$ post-operative hour in comparison to the ECW before surgery (period 0-24) in groups $\mathrm{N}$ and OL. Additionally, in time period 24-48, there was a significant $(p<0.05)$ ECW decrease in group OS and OL.

Correlation between ECW and the patients' age and BMI values showed significant negative correlations between ECW evaluated in the studied time points and patient's age in group $\mathrm{N}$ (time point 0 : $r=-0.596, p=0.041$; time point $24: r=-0.577$, $p=0.049$; time point $48 r=-0.658, p=0.02)$. ECW positively correlated with the patients' BMI in the three studied time points (time point 0: $r=0.809$, $p<0.001$; time point 24: $r=0.720, p=0.001$; time point 48: $r=0.786, p<0.001)$ in group OS. In group OL, positive correlation $(r=0.473, p=0.035)$ was observed between ECW and patients' BMI in the time point 48.

\section{Intracellular water}

No significant differences in ICW were observed between groups OS and $\mathrm{N}$ as well as between groups OL and OS in the studied time points. Results are presented in Table 4.

No changes in the ICW amount in the studied time periods were observed in the studied groups.

A significant negative $(r=-0.620, p=0.031)$ correlation between ICW, evaluated in the time point 24 , and patients' BMI was observed in group N. There were no significant correlations between ICW and patients' age and BMI values in the studied time point in group OS and OL.

\section{Extracellular water/intracellular water ratio}

The ratio of ECW/ICW did not differ significantly between group OS and N, and OL and OS in the studied time points (Table 5). However, tendency to higher ECW/ICW was observed in group OS in comparison to group $\mathrm{N}$ in the three studied time periods. 
Table 4. Median of patients' intracellular water (ICW) in groups N, OS, and OL before surgery, 24, and 48 hours after the surgery

\begin{tabular}{|c|c|c|c|}
\hline \multirow[t]{2}{*}{ Factor } & Group N & Group OS & Group OL \\
\hline & $\begin{array}{l}\text { Median } \\
\text { Min-max } \\
\text { (l) }\end{array}$ & $\begin{array}{l}\text { Median } \\
\text { Min-max } \\
\text { (l) }\end{array}$ & $\begin{array}{l}\text { Median } \\
\text { Min-max } \\
\text { (l) }\end{array}$ \\
\hline $\begin{array}{l}\text { ICW } \\
\text { Time point } 0\end{array}$ & $\begin{array}{c}16.00 \\
14.30-21.90\end{array}$ & $\begin{array}{c}18.10 \\
14.80-31.40\end{array}$ & $\begin{array}{c}17.55 \\
14.10-25.40\end{array}$ \\
\hline $\begin{array}{l}\text { ICW } \\
\text { Time point } 24\end{array}$ & $\begin{array}{c}15.40 \\
13.70-19.30\end{array}$ & $\begin{array}{c}17.40 \\
14.20-27.80\end{array}$ & $\begin{array}{c}17.65 \\
13.30-21.80\end{array}$ \\
\hline $\begin{array}{l}\text { ICW } \\
\text { Time point } 48\end{array}$ & $\begin{array}{c}15.30 \\
12.90-24.50\end{array}$ & $\begin{array}{c}17.20 \\
14.20-27.80\end{array}$ & $\begin{array}{c}17.50 \\
15.20-20.30\end{array}$ \\
\hline
\end{tabular}

Min-max - range of values

Table 5. Median of patients' extracellular water (ECW)/intracellular water (ICW) in groups N, OS, and OL before surgery, 24, and 48 hours after the surgery

\begin{tabular}{|c|c|c|c|}
\hline \multirow[t]{2}{*}{ Factor } & Group N & Group OS & Group OL \\
\hline & $\begin{array}{c}\text { Median } \\
\text { Min-max } \\
\text { (l) }\end{array}$ & $\begin{array}{l}\text { Median } \\
\text { Min-max } \\
\text { (l) }\end{array}$ & $\begin{array}{c}\text { Median } \\
\text { Min-max } \\
\text { (l) }\end{array}$ \\
\hline $\begin{array}{l}\text { ECW/ICW } \\
\text { Time point } 0\end{array}$ & $\begin{array}{c}0.77 \\
0.54-0.90\end{array}$ & $\begin{array}{c}0.87 \\
0.01-1.01\end{array}$ & $\begin{array}{c}0.85 \\
0.66-1.09\end{array}$ \\
\hline $\begin{array}{l}\text { ECW/ICW } \\
\text { Time point } 24\end{array}$ & $\begin{array}{c}0.84 \\
0.63-0.93\end{array}$ & $\begin{array}{c}0.91 \\
0.49-1.02\end{array}$ & $\begin{array}{c}0.88 \\
0.72-1.12\end{array}$ \\
\hline $\begin{array}{l}\text { ECWICW } \\
\text { Time point } 48\end{array}$ & $\begin{array}{c}0.81 \\
0.46-0.93\end{array}$ & $\begin{array}{c}0.89 \\
0.52-1.02\end{array}$ & $\begin{array}{c}0.88 \\
0.77-1.04\end{array}$ \\
\hline
\end{tabular}

Min-max-range of values

Table 6. Median of patients' overhydration $(\mathrm{OH})$ in groups $\mathrm{N}, \mathrm{OS}$, and OL before surgery, 24, and 48 hours after the surgery

\begin{tabular}{|lccc|}
\hline Factor & Group N & Group OS & Group OL \\
\cline { 2 - 4 } & Median & Median & Median \\
& Min-max & Min-max & Min-max \\
& $(\mathrm{I})$ & $-(\mathrm{l})$ & -1.40 \\
$\mathrm{OH}$ & -0.65 & -1.15 & $-5.40-0.60$ \\
Time point 0 & $-4.00-1.00$ & $-7.20-0.60$ & -0.85 \\
$\mathrm{OH}$ & 0.20 & -1.40 & $-3.40-1.00$ \\
Time point 24* & $-1.80-1.10$ & $-6.50-0.80$ & -1.10 \\
OH & 0.15 & -1.30 & $-3.00-0.80$ \\
Time point 48* & $-5.60-1.30$ & $-6.80-0.60$ & \\
\hline
\end{tabular}

Min-max - range of values

* - statistically significant difference in Mann Whitney U-test group N vs. OS

There was a significant $(p=0.034)$ increase of ECW/ICW ratio in the time period $0-24$ in group $\mathrm{N}$. No significant changes were observed in group OS and OL in the studied time periods.
ECW/ICW ratio correlates positively $(r=0.639$, $p=0.025)$ with patient's BMI values in the time point 24 in group N. No significant correlations were observed in group OS and OL. 


\section{Overhydration status}

Overhydration status $(\mathrm{OH})$ was significantly higher in the $24^{\text {th }}$ and $48^{\text {th }}$ hour after the surgery $(p=0.009$ - time point $24 ; p=0.012$ - time point 48 ) in group $\mathrm{N}$ in comparison to group OS. There were no statistically significant differences in the $\mathrm{OH}$ between the patients of group OL and OS at the studied time points. This is presented in Table 6 .

A significant increase of $\mathrm{OH}$ in the $24^{\text {th }}$ postoperative hour compared to the state before operation (period 0-24) was observed in group N, while a significant decrease in the same time period was observed in group OL. In group OS, there was no change of $\mathrm{OH}$ in the studied time periods.

Correlation between the $\mathrm{OH}$ and the patients' age and BMI values did not show significant correlations in the studied groups in the investigated time points.

The total fluid administration within the first 24 hours after the surgery in group $\mathrm{N}$ was $2,500 \mathrm{ml}$ (range, 1,500-3,500 ml), in group OS 2,625 ml (range, $2500-3500 \mathrm{ml}$ ), and in group OL was 2,500 $\mathrm{ml}$ (range, $1,000-3500 \mathrm{ml}$ ). During the next 24 hours, none of the patients required fluid administration.

\section{Discussion}

The determination of the body water amount and its distribution between the extracellular and intracellular compartments allows for the assessment of the body water balance as well as its disturbances [14]. The TBW and ICW is lower in women than in men and decreases along with age $[15,16]$. Changes in the hydration status were observed in obese patients in whom the development of adipose tissue deposit was accompanied by the increase of the ECW, compared to the ICW [7]. From a clinical point of view, the hydration status is a major factor for the applicability of appropriate treatment and the inclusion of drugs regulating the state of overhydration or dehydration [18]. Knowledge of the optimum state of hydration is particularly important in patients with diagnosed chronic kidney disease to stratify prognosis, evaluate an effective treatment, and to appropriately qualify patients for renal replacement therapy [19]. Hydration status affects the course of the early post-operative period and its balance helps to reduce incidents of PONV, especially in patients operated with the use of a laparoscopic technique, and improves wound healing as well as shortenes the period of hospitalization [10, 20, 21].

In the presented study, we evaluated the TBW, ECW, and ICW, ECW/ICW ratio as well as the state of $\mathrm{OH}$ in obese patients (group OS) compared to patients with normal weight (group N), who underwent laparoscopic cholecystectomy with standard intraabdominal pressure, and evaluated differences between obese female patients undergoing laparoscopic surgery with creation of standard (group OS) and low intra-abdominal pressure (OL group) in the three time points: before surgery and in the $24^{\text {th }}$ and $48^{\text {th }}$ hour after surgery.

A higher TBW was observed in obese patients compared to patients with normal weight before surgery, in the $24^{\text {th }}$ and $48^{\text {th }}$ hour after surgery. TBW did not differ significantly between groups OS and OL in any of the studied time points.

Similar results of a higher TBW in obese women compared to women with normal body weight were obtained by Sartolio et al. [22]. The results, indicating a higher TBW in obese patients were received by Resende et al., studying a group of people aged 10-19 [23]. Higher TBW in obese women compared to women of normal weight was also described in the study of Silva et al., who examined a population of 371 women [24].

The TBW varies with age; its decrease begins in middle-aged men and especially after the age of 60 in women $[25,26]$. The mean TBW decrease between the age of 20 and 80 is about 4 and 6 liters, respectively, in men and women $[27,28]$. In our study in the time point 24 , we observed TBW decrease with the patients' age in group N, what can confirm described above correlations. This change may result from the reduction of intracellular water and body cell mass during the aging process $[25,26]$.

In our study, ECW was significantly higher in group OS as compared to group $\mathrm{N}$ before surgery, in the $24^{\text {th }}$, and $48^{\text {th }}$ hour after surgery. There was no difference in the ECW between obese female patients operated on using two different values of intraabdominal pressure in the studied time points. A higher ECW in obese women compared to women of normal weight has been described in a study by Waki et al. [29]. Silva et al. described a further increase of ECW accompanying weight gain [24]. This data correlates with the results obtained in our study, in which a positive correlation was observed between ECW and the patient's BMI values in the three studied time points in group OS. These findings may indicate an increase of the extracellular compartment in obese patients, thus increasing the ECW, which in turn increases the TBW in obesity.

In our study, ICW did not differ significantly between groups OS and $\mathrm{N}$, and between groups OS and $\mathrm{OL}$ in the studied time points. However, there are reports suggesting higher ICW in obese women compared to women with normal body weight [29].

In our study, neither TBW nor ECW or ICW did not differ significantly between obese female patients who underwent laparoscopic procedures with two different pneumoperitoneum pressures (group OS vs. OL). These observations may be explained by the fact that the standard value of the insufflated gas is not enough to cause the changes in the fluids 
compartments. It can be suggested that differences between pressure values used in our study were too low and thus, no changes were reported. Additionally, it may result from the short duration of pneumoperitoneum during laparoscopic cholecystectomies in our study, not enough to influence the patients' hydration status.

Obesity is characterized by an increase in fat mass and increased fat-free mass, and thus enlarged extracellular water compartment compared with the intracellular water compartment. This can be explained by a high ECW/ICW ratio of the adipose tissue $[17,30]$.

In our study, there was no difference in the ECW/ ICW ratio between obese patients from group OS and normal weight patients in the studied time points. Additionally, there was no difference in the ECW/ICW ratio between both obese patients' groups OS and OL. Different results compared to those obtained in our study were described by Waki et al., who reported a higher ECW/ICW ratio in obese women compared to women of normal weight [29]. A higher ICW/ECW ratio has also been described by Mazariegos et al. in obese patients classified to surgical treatment of obesity, as compared to patients with normal body weight $[30,31]$. It may suggest that the significant differences, which were not observed in our study can be visible when the difference of BMI values is higher than observed among patients enrolled to our research.

Surgical interventions, even with usage of minimally invasive techniques, cause the stress-induced release of aldosterone, antidiuretic hormone as well as activation of the renin-angiotensin system, which leads to sodium and water retention. Furthermore, the release of inflammatory mediators in response to surgical trauma may result in SIRS, increased capillary permeability, and water shift from intravascular compartment into the interstitial space [32, 33]. Peripheral and visceral edema, usually seen after major abdominal surgeries and liberal fluid administration, also in trauma patients, is a manifestation of increased capillary permeability and overhydration [34-36].

In our study, higher dehydration in group OS in the $24^{\text {th }}$ and $48^{\text {th }}$ hour after surgery, compared to group $\mathrm{N}$ was reported. In both OL and OS there was no difference in the state of overhydration. Our observations are similar to the observations by Leonea et al. who reported that obese patients undergoing bariatric surgery are relatively more dehydrated compared to those who have never been obese [37]. It can be explained by the fact that the excess amount of adipose tissue has no capacity to store water. Therefore, larger deficiency of water occurs in obese individuals [29].

\section{Conclusions}

To conclude, it can be stated that obesity alters the hydration status. Obese female patients are characterized by the higher TBW and ECW in comparison to normal weighted females who undergo short-term laparoscopic surgery. Values of carbon-dioxide pneumoperitoneum pressure used during laparoscopic cholecystectomy did not have an influence on the hydration status of the obese female patients. Thus, lowpressure pneumoperitoneum does not seem to offer advantages over standard-pressure pneumoperitoneum in measured parameters of hydration status. However, we plan to extend our study on a group of patients, where the time of carbon dioxide pneumoperitoneum exposure will be longer. We expect that our results would put a new insight into the influence of the pneumoperitoneum on the hydration status and therefore, on the proper fluid management and the course of the early post-operative period.

\section{Conflict of interest}

The authors declare no conflict of interest.

\section{References}

1. Formiguera X, Cantón A. Obesity: epidemiology and clinical aspects. Best Pract Res Clin Gastroenterol 2004; 18 : 1125-1146.

2. Arroyo-Johnson C, Mincey KD. Obesity Epidemiology Worldwide. Gastroenterol Clin North Am 2016; 45: 571-579.

3. Zahorska-Markiewicz B, Mucha Z. Otyłość i leczenie operacyjne. Chirurgia Polska 2001; 3: 79-83.

4. Sidhu RS, Raj PK, Treat RC, Scarcipino MA, Tarr SM. Obesity as a factor in laparoscopic cholecystectomy. Surg Endosc 2007; 21: 774-776.

5. Litwin DE, Cahan MA. Laparoscopic cholecystectomy. Surg Clin North Am 2008; 88: 1295-1313.

6. Brokelman WJ, Lensvelt M, Borel Rinkes IH, Klinkenbijl JH, Reijnen MM. Peritoneal changes due to laparoscopic surgery. Surg Endosc 2011; 25: 1-9.

7. Nguyen NT, Wolfe BM. The physiologic effects of pneumoperitoneum in the morbidly obese. Ann Surg 2005; 241 : 219-226.

8. Mulier JP, Garcia M, Dillemans B. Pathophysiology of obesity. Impact on laparoscopy. Acta Anaesthesiol Belg 2009; 60: 149-153.

9. Doubravska L, Dostalova K, Fritscherova S, Zapletalova J, Adamus M. Incidence of postoperative nausea and vomiting in patients at a University Hospital. Where are we today? Biomed Pap Med Fac Univ Palacky Olomouc Czech Repub 2010; 154: 69-76.

10. Gan TJ, Soppitt A, Maroof M, el-Moalem H, Robertson KM, Moretti E, Dwane P, Glass PS. Goal-directed intraoperative fluid administration reduces length of hospital stay after major surgery. Anesthesiology 2002; 97: 820-826.

11. Mythen MG, Webb AR. Perioperative plasma volume expansion reduces the incidence of gut mucosal hypoperfusion during cardiac surgery. Arch Surg 1995; 130: 423-429.

12. Das SK. Body composition measurement in severe obesity. Curr Opin Clin Nutr Metab Care 2005; 8: 602-606.

13. Chumlea WC, Schubert CM, Sun SS, Demerath E, Towne B, Siervogel RM. A review of body water status and the effects of age and body fatness in children and adults. J Nutr Health Aging 2007; 11: 111-118. 
14. Vahidi H, Talebpour A, Tabatabaie O, Talebpour M. Changes in the body composition after laparoscopic gastric plication: a short-term prospective case series. Surg Obes Relat Dis 2016; 12: 577-581.

15. Baker SP, Shock NW, Norris AH. Influence of age and obesity in women on basal oxygen consumption expressed in terms of total body water and intracellular water. In: Biological Aspects of Aging. Shock NW (ed.). Columbia University Press, New York 1962; 84-91.

16. Steele JM, Bergery EY, Dunning MF, Brodie BB. Total body water in man. Am J Physiol 1950; 162: 313-317.

17. Marken Lichtenbelt WD, Fogelholm M. Increased extracellular water compartment, relative to intracellular water compartment, after weight reduction. J Appl Physiol 1999; 87: 294-298.

18. Lukaski HC. Methods for the assessment of human body composition: Traditional and new. Am J Clin Nutr 1987; 47: 537-556.

19. Załuska W, Bednarek-Skublewska A, Szeliga-Król J, Załuska A, Ksiązek A. Zastosowanie analizatora składu ciała ludzkiego do oceny nawodnienia u pacjentów leczonych metodą hemodializy z powodu schyłkowej niewydolności nerek. Nefrol Dializoter Pol 2010; 14: 195-196.

20. Adanir T, Aksun M, Ozgürbüz U, Altin F, Sencan A. Does preoperative hydration affect postoperative nausea and vomiting? A randomized, controlled trial. J Laparoendosc Adv Surg Tech A 2008; 18: 1-4.

21. Mythen MG, Webb AR. Perioperative plasma volume expansion reduces the incidence of gut mucosal hypoperfusion during cardiac surgery. Arch Surg 1995; 130: 423-429.

22. Sartorio A, Malavolti M, Agosti F, Marinone PG, Caiti O, Battistini N, Bedogni G. Body water distribution in severe obesity and its assessment from eight-polar bioelectrical impedance analysis. Eur J Clin Nutr 2005; 59: 155-160.

23. Resende CM, Camelo Júnior JS, Vieira MN, Ferriolli E, Pfrimer K, Perdoná GS, Monteiro JP. Body composition measures of obese adolescents by the deuterium oxide dilution method and by bioelectrical impedance. Braz J Med Biol Res 2011; 44: 1164-1170.

24. Silva AM, Heymsfield SB, Gallagher D, Albu J, Pi-Sunyer XF Pierson RN Jr, Wang J, Heshka S, Sardinha LB, Wang Z. Evaluation of between-methods agreement of extracellular water measurements in adults and children. Am J Clin Nutr 2008; 88: 315-323.

25. Schoeller DA. Changes in total body water with age. Am J Clin Nutr 1989; 50: 1178-1181.

26. Steen B. Body water in the elderly: A review. J Nutr Health Aging 1997; 1: 142-145.

27. Lesser GT, Markofsky J. Body water compartments with human aging using fat-free mass as the reference standard. Am J Physiol 1979; 236: 215-220.

28. Chumlea WC, Guo SS, Zeller CM, Reo NV, Siervogel RM. Total body water data for white adults 18 to 64 years of age: the Fels Longitudinal Study. Kidney Int 1999; 56: 244-252.

29. Waki M, Kral JG, Mazariegos M, Wang J, Pierson RN Jr, Heymsfield SB. Relative expansion of extracellular fluid in obese vs. nonobese women. Am J Physiol 1991; 261: 199-203.

30. Wang J, Pierson RN. Disparate hydration of adipose and lean tissue requires a new model for body water distribution in man. J Nutr 1976; 106: 1687-1693.

31. Mazariegos M, Kral JG, Wang J, Waki M, Heymsfield SB, Pierson RN Jr., Thornton JC, Yasumura S. Body composi- tion and surgical treatment of obesity. Effects of weight loss on fluid distribution. Ann Surg 1992; 216: 69-73.

32. Desborough JP. The stress response to trauma and surgery. Br J Anaesth 2000; 85: 109-117.

33. Holte K, Sharrock NE, Kehlet H. Pathophysiology and clinical implications of perioperative fluid excess. Br J Anaesth 2002; 89: 622-632.

34. Ertel W, Oberholzer A, Platz A, Stocker R, Trentz O. Incidence and clinical pattern of the abdominal compartment syndrome after "damage-control" laparotomy in 311 patients with severe abdominal and/or pelvic trauma. Crit Care Med 2000; 28: 1747-1753.

35. Balogh Z, McKinley BA, Cocanour CS, Kozar RA, Valdivia A, Sailors RM, Moore FA. Supranormal trauma resuscitation causes more cases of abdominal compartment syndrome. Arch Surg 2003; 138: 637-643.

36. Mayberry JC, Welker KJ, Goldman RK, Mullins RJ. Mechanism of acute ascites formation after trauma resuscitation. Arch Surg 2003; 138: 773-776.

37. Leone PA, Gallagher D, Wang J, Heymsfield SB. Relative overhydration of fat-free mass in postobese versus neverobese subjects. Ann N Y Acad Sci 2000; 904: 514-519.

\section{Address for correspondence:}

Łukasz Pietrzyk, MD, PhD

Department of Didactics and Medical Simulation

Chair of Human Anatomy, Medical University of Lublin

4 Jaczewskiego St.

20-094 Lublin, Poland

Phone: +48 505918705

Fax: +48 814486050

Email: lukasz.pietrzyk@wp.pl 